http://jmscr.igmpublication.org/home/ ISSN (e)-2347-176x ISSN (p) 2455-0450 crossref DOI: https://dx.doi.org/10.18535/jmscr/v8i6.66

\author{
Journal Of Medical Science And Clinical Research \\ IGM Publication \\ An Official Publication of IGM Publication
}

\title{
Role of Haritaki in Tamaka shwasa: A conceptual study
}

\author{
Authors \\ Vd.Balaji Sawant $^{\# 1}$, Vd. Swati Kansal ${ }^{* 2}$, Vd. Abhilasha ${ }^{\# 3}$ \\ ${ }^{1}$ Professor and H.O.D. Dravya Guna Dept, Smt K.G.Mittal P. Ayurvedic College, Mumbai \\ ${ }^{2}$ PG Scholar, Dravya Guna Dept., Smt K.G.Mittal P. Ayurvedic College, Mumbai \\ ${ }^{3}$ PG Scholar, Shalakaya Tantra Dept., Uttarakhand Ayurveda University, Gurukul Campus, Haridwar
}

\begin{abstract}
Chronic recurrent airway disorders are increasingly seen all over the global population, especially in the last few years. In Ayurveda one such disorder is Tamaka Shwasa. In Tamaka Shwasa patient feels excessive thirst and there is characteristic sound from throat while breathing (कण्घुर्घुरिकान्वित). It is correlated with Bronchial Asthma in Allopathy. Around 339 million people are living with asthma worldwide ${ }^{[1]}$. It causes sleep disturbance, restlessness and social stigma especially in school going children. According to Ayurveda classics Tamaka Shwasa is Pitta Sthana Samudbhava Vyadhi. On the other hand Bronchial Asthma is a chronic inflammatory disease of airways. It leads to recurrent episodes of wheezing, breathlessness, tightness of chest and cough particularly at night or early morning. In modern medicine while main emphasis is given to antispasmodic drugs for its management, in Ayurveda contrary to that main emphasis is given to its place of origin which is pitta sthana. So treatment is given in accordance with udbhav sthana that's why ancient scholars use Haritaki (Terminalia chebula) and its formulations to cure Tamaka shwasa. Haritaki due to its purgative property cleanses the stomach and small intestine and therefore brings back the vitiated kapha back to its original place.
\end{abstract}

Keywords: Tamaka shwasa, bronchial asthma, haritaki.

\section{Introduction}

Research in respiratory diseases is a must in the present era because of many factors like air pollution, dietary habits, crowds, low immunity of people etc. One such disease is shwasa which in Ayurveda is defined as "श्वास्: तु भस्त्रिका आध्मान् सम् वातो ऊर्धवगामिता"। It is a stage of dyspnoea. It occurs due to kapha pradhana vata vikara (prana evam udana vayu). According to modern science, due to the inflammation of mucous membrane of respiratory tract (bronchi, bronchioles etc) there occurs obstruction in vata marga and due to the stimulation of vagus nerve, respiratory muscles contracts which further makes vata marga even more obstructed and leads to the difficulty in breathing.

कफ वातात्मकावेतौ पित्तस्थान समुद्धवौ।

ह्रद्यस्य रसादीनाम् धातूनाम् च् उप्शोषणो॥ (च.चि.१७/८) [२] $^{[?]}$

निदान:

रजसा धूमवाताभ्याम् शीतस्थानाम्बुसेवनात्।

व्यायामाद् ग्राम्यधर्माध्वरूक्षात्रविषमाश्नात्॥ आमप्रदोषात् आनाहाद् रोक्ष्याद् अति अपतर्पणात्| दौर्बल्यात् मर्मणो घाताद् द्वन्द्वाच्छुध्तियोगत: ॥ 
अतिसार ज्वर छ्रदि प्रतिश्याय् क्षत् क्षयात् ॥

रक्तपिताद् उदावर्ताद् विसूच्यलसकादपि ॥ पाण्डुरोगाद् विशात् चैव प्रवर्तते गदाविमौ ॥

निष्पावमाषपिण्याकतिलतैलनिषेवणात् ।

पिष्टशालूकविष्टम्भिविदाहीगुरूभोजनात् ।

जलजानूपपिशितदध्यामक्षीरसेन्नात् ।

अभिष्यन्दि उपचारात् च् श्लेष्मलानाम् च् सेवनात्।

कण्ठरस: प्रतीघाताद् विबन्धै च् प्रिथक् विधै:॥

(च.चि.१७/११-१६) ${ }^{[3]}$

श्वास सम्प्राप्ति :

यदा स्त्रोतान्सि सत्रुध्य मारुत: कफपूर्वक:।

विष्वग्व्रजति सत्रुध्: तदा श्वासान् करोति स: ॥

(च चि $९ ७ / ४ ५)^{[४]}$

In general Shwasa roga may occur due to following three reasons:

(a) Defect in respiratory system due to congestive heart failure, diabetic coma, epidemic dropsy.

(b) Obstruction in respiratory passage which makes the space less available for vaat movement: it may occur due to tundikashoth, rohini etc

(c) Dysfunctioning of accessory respiratory muscles due to abdominal inflammation, emphysema, jalodara etc.

Ayurveda considers Shwasa roga originates from pitta sthana which can be considered as stomach and small intestine, so the main aim of treatment is to use drugs which act on these sites so that vitiated kapha can be controlled and then automatically vitiated vata will be under control. So for this purpose in Ayurveda haritaki is used as it cleans the passage by letting stool because of its purgative property. Haritaki is the best mriduvirechaka Dravya. According to Acharya Charak management of Tamaka shwasa includes snehana-swedana and then Vamana (Therapeutic emesis) and Virechana (Therapeutic purgation).

Is Bronchial Asthma mentioned in Ayurveda? Yes. In Ayurveda this disease is described in the name of Tamaka Swasa, one of the five varieties of Swasa. ${ }^{[14]}$ www.ccras.nic.in

Samprapti ghataka of Tamaka shwasa:
Dosh: vata and kapha

Dushya : pranvah,annavah and udakvah strotas

Adhishthan : pranvah, udanvah strotas

Strotodushti prakar: vimarga gaman , sanga

Agni sthithi: agnimandya

Sadhya-asadhyata : yapya, if it is new then it is sadhya acc to Acharya Charaka.

\section{Aims and Objectives}

1. To study the etiopathogenesis of Tamaka shwasa worst bronchial asthma

2. To evaluate the role of Haritaki in tamaka shwasa.

\section{Materials \& Methods}

\section{Literary Source of Drugs}

हरीतकी पचचरसा अलवणा तुवरा परम् ।

रूक्ष् ऊष्णा दीपनी मेध्या स्वादु पाका रसायनी॥

चक्षुष्या लघु आयुष्या बृंहणी चानुलोमिनी।

श्वासकासप्रमेहार्श: कुष्ठ शोथोदरक्रिमीन् ॥

(भाव प्रकाश् निघण्टु हरीक्क्यादि वर्ग १९-२०)[५]

Haritaki by acharya Charaka

कफ प्रसेकम् वैस्वरयम् वैवर्यम् कामलाम् कृमीन् । श्यथुम् तमकम् छर्दिम् क्लैब्यम् अन्गव्सादनम् ॥ (ch chikitsa 1/ 33) $)^{[\xi]}$

Shwas roga is of 5 types among which one is tamaka shwasa samprapti of Tamaka shwasa:

प्रतिलोमम् यदा वायु: स्तोतान्सि प्रतिपध्यते। ग्रीवाम् शिर्: च् संगृह्य श्लेष्माणम् समुदीर्य च ॥ करोति पीनसम् तेन रुधो घुर्घुरकम् तथा ।

अतीव तीव्रवेगम् च श्वासम् प्राणप्रपीडकम् ॥ (च.चि. १७/५५-५६ $)^{[8]}$

A. Lakshana of tamaka shwasa

- Glani anubhav

- Kaaste sanirudhyate(on and off coughing)

- Pramoh

- Excessive pain during expectoration

- Feeling of relaxness after expectoration

- Kanth udhvansa

- Difficulty in speaking 
- Unable to sleep

- Parshwa pradeshagat peeda

- Feel comfort while sitting instead of lying down

- Likeness of warm environment and hot eatables

- Uchrit aksha (eyeballs turn upwards)

- Excessive Sweating on forehead

- Dryness of mouth

- Futkar karke shwas aana (फूत्कार कर् के श्वास आना)

Tamaka shwas increases during cloudy season , due to use of cold water and kaph vardhak padarthas.

According to acharya Charaka tamaka shwasa is yapya although new one is sadhya

Tamaka shwas is considered "pran peedaka".

B. Pratamak shwasa

Pratamak shwasa $=$ tamaka shwas+jwara + murcha.

C. Santamaka shwasa

उदावर्त रजो अजीर्ण क्लिन्कायनिरोधज:।

तमसा वर्धते अत्यर्थम शीते: च आशु प्रशाम्यति।

मजजत: तमसीवा अस्य विध्यात् सन्तमकम् तु तम्॥[9]

(च चि १७/६३-६४)

\section{Purva roopa of shwasa}

charaka Sushruta vagbhatta

Madhava

Aanah Hritpeeda Hrit parshwashoolam Hritpeeda

ParshwashoolaBhakar dwesha Pranvilomta Shoola

Hridya peedan Arti Aanaha Adhman

Pran vilom Aanah shankhbheda Aanah

\section{Management of tamaka shwasa}

1. Acharya Charaka said first of all do snehana swedana and then vamana karma has to be done to remove kapha.

2. In chapter 1 of Charak Samhita Chikitsa Sthana Acharya Charaka mentioned the use of Haritaki in Tamaka shwasa.

कफ प्रसेकम् वैस्वरयम् वैवर्ण्यम् कामलाम् कृमीन् ।
श्यथुम् तमकम् छर्दिम् क्लैब्यम् अन्गव्सादनम् ॥

(ch chikitsa 1/33) ${ }^{[6]}$

3. As haritaki is of ushna veerya so it acts mainly on dushita kapha and vata and thereby helps in curing htamaka shwasa

4. Use of haritaki formulations as Agstaya haritaki and Vyaghra haritaki mentioned in ayurvedic classics for tamaka shwasa.

5. Vyaghra haritaki

क्षयोद्धवम् च क्षतजम् च हन्यात् सपीनसश्वासस्वरक्षयम् च

यक्ष्माणमेकादशमुग्ररूपम् भृगूप्दिष्ट् हि रसायनम् स्यात्॥

(भैषज्यरतावली कासे अध्याय १७२ श्लोक)

6. Ashtang hridya as tamaka shwasa occurs due to obstruction of vata by kapha so to clear vata marga vamana and virechana are necessary. As haritaki is a good virechaka dravya so it is a good drug to cure tamaka shwasa.

7. घृत् क्षौद्रेण् वा पथ्या विडंग ऊष्णा पिप्पलि: ॥ (अष्टांग ह्रदय चि 4/41) ${ }^{[10]}$

8. Use of tejovatyadi ghrut (haritaki as a content) is mentioned in Ashtang Hridya for curing Tamaka shwasa.

9. One another formula mentioned in ashtang hridya for Tamaka shwasa is Pippli + pipplimool + harad + vidang + chitrak ke kalka se ghee ki handi me lepa kre .when this lepa become dry then add takra in this handi. Ek maas tak pada wah takra is agneedeepak and kaas shwasa nashak ${ }^{[11]}$

\section{Conclusions}

According to Acharya Charak the intelligent physician should give Chhardana (emesis) medicated with drugs alleviating Vata and Kapha to patients suffering from Kasa and Swarbhanga along with Shwasa. He should give Virechana medicated with drug alleviating Vata and Kapha. Charak and Vagbhata described Shwasa as a disease in which Virechana is indicated. In Tamaka Swasa- Kapha obstructs the marga (passage) of Vayu. The obstructed Vayu take the 
Pratiloma gati (Vimargagamana) and Virechana drugs have a quality of Vatanulomana, Kaphavataghna karma, Ushna Veerya may be more beneficial in the condition of Shwasa. Virechana drugs remove mainly Kapha and Pitta Doshas and make Vata in Anuloma gati. The origin of Shwasa roga is Pitta sthna and Virechana purifies the Pitta sthana which in fact is the site of origin of Shwasa roga. Hence, it acts as a curative measure. \{A CRITICAL REVIEW STUDY ON TAMAK SHWASA (BRONCHIAL ASTHMA): AN AYURVEDIC PROSPECTIVE Dr. Archana Nivrutti Bhangare* 1 and Sandeep Madhukar Lahange2 WORLD JOURNAL OF PHARMACEUTICAL AND MEDICAL RESEARCH www.wjpmr.com ${ }^{[12]}$

Finally as said in materia medica too, the primary aim of ayurvedic treatment in Tamaka shwasa is to correct pitta sthana by giving emetic therapy or by giving medicines which will keep the bowels clean. Haritaki along with other medicines is useful in correcting this as all preparations indicated for Tamaka shwasa contains haritaki ${ }^{[15]}$

\section{References}

1. https://www.who.int

2. Charak samhita chikitsa sthan adhyaya 17 shlok number 8 page no417, edited by Acharya Vidyadhar Shukla and Prof Ravi Dutt Tripathi Chuakhamba Sanskrit pratishthan,2012.

3. Charak samhita chikitsa sthan adhyaya 17 shlok number 11 to 16 page no418, edited by Acharya Vidyadhar Shukla and Prof Ravi Dutt Tripathi Chuakhamba Sanskrit pratishthan,2012.

4. Charak samhita chikitsa sthan adhyaya 17 shlok number 45 page no 422 , edited by Acharya Vidyadhar Shukla and Prof Ravi Dutt Tripathi Chuakhamba Sanskrit pratishthan,2012.

5. Bhav prakash nighantu haritkyadi varga shlok no 19,20 page no 5 , commentary by Prof K.C.Chunekar, edited by Dr. G.S.
Pandey, Chaukhamba Bharati Academy, 2010.

6. Charak samhita chikitsa sthan adhyaya 1 shlok number 33 page no 8 , edited by Acharya Vidyadhar Shukla and Prof Ravi Dutt Tripathi Chuakhamba Sanskrit pratishthan, 2012.

7. (https://doi.org/10.1155/2013/650134

Antitussive Activity of the WaterExtracted Carbohydrate Polymer from Terminalia chebula on Citric Acid-Induced Cough by Gabriela Nosalova,1 Ludovit Jurecek,1 Udipta Ranjan Chatterjee,2 Sujay Kumar Majee,2 Slavomir Nosal,3 and Bimalendu Ray2)

8. Charak samhita chikitsa sthan adhyaya 17 shlok number 55-56 page no424, edited by Acharya Vidyadhar Shukla and Prof Ravi Dutt Tripathi Chuakhamba Sanskrit pratishthan,2012.

9. Charak samhita chikitsa sthan adhyaya 17 shlok number 63-64 page no 425, edited by Acharya Vidyadhar Shukla and Prof Ravi Dutt Tripathi Chuakhamba Sanskrit pratishthan,2012.

10. Ashtang hridya chikitsa sthana adhyaya 4 shlok 41 page no 434, by Kaviraja Atrideva Gupta, edited by Vaidya Yadunandan Upadhyaya, Chaukhamba Prakashan,2011.

11. Ashtang hridya chikitsa sthana adhyaya 4 shlok 29-30 page no 433, by Kaviraja Atrideva Gupta, edited by Vaidya Yadunandan Upadhyaya, Chaukhamba Prakashan,2011.

12. A CRITICAL REVIEW STUDY ON TAMAK SHWASA (BRONCHIAL ASTHMA): AN AYURVEDIC PROSPECTIVE Dr. Archana Nivrutti Bhangare and Sandeep Madhukar Lahange WORLD JOURNAL OF PHARMACEUTICAL AND MEDICAL RESEARCH www.wjpmr.com

13. www.ccras.nic.in 
14. Materia medica of Ayurveda page no xlvixlvii introduction, by Vd. Bhagwan Dash, Vd. Lalitesh Kashyap, published by Naurang Rai, Concept publishing company, New Delhi, 198. 